\title{
Evaluation of Antioxidant activities of Brassica napus's seeds by CUPRAC, ABTS/Persulphate and DMPD methods
}

\author{
Ayca KARASAKAL
}

\begin{abstract}
The antioxidant activities of the extracts prepared from Brassica napus's seeds (canola seeds) was determined in this study. Brassica napus's seeds were collected from eight different regions of Turkey. Extraction experiments were carried out with $100 \%$ hexane, $100 \%$ acetone, $100 \%$ methanol, $100 \%$ ethanol, $\% 75$ hexane-water, $\% 75$ acetone-water , $75 \%$ methanol-water, $75 \%$ ethanol-water, $\% 50$ hexane-water, $50 \%$ acetone-water, $50 \%$ methanol-water, $50 \%$ ethanol-water at $25{ }^{\circ} \mathrm{C}$ overnight and were mixed by magnetic stirrer during $1 \mathrm{~h}, 2 \mathrm{~h}, 4 \mathrm{~h}, 8 \mathrm{~h}$ to determine optimal extraction conditions. According to the results of UV/VIS spectra, $100 \%$ hexane extraction managed at $25^{\circ} \mathrm{C}$ overnight was chosen for working with ABTS/
\end{abstract}

Persulphate, N,N-dimethyl-p-phenylenediamine (DMPD) and CUPRAC methods. CUPRAC and ABTS/Persulphate methods's total antioxidant capacity (TAC) were calculated as Trolox equivalent. In DMPD method, antioxidant capacity of the extracts was determined by inhibition of DMPD radical cation. DMPD method analysis results of Brassica napus's seeds showed the greatest effectiveness, with inhibition values of 2.00 $\pm 0.07 \%$ and $17.1 \pm 0.03 \%$. The antioxidant activities of Brassica napus's seeds ranged from $0.29 \pm 0.04 \mathrm{~mol} / \mathrm{g}$ and $0.48 \pm 0.01$ $\mathrm{mol} / \mathrm{g}$ for CUPRAC method and $0.36 \pm 0.01 \mathrm{~mol} / \mathrm{g}$ and $0.55 \pm$ $0.05 \mathrm{~mol} / \mathrm{g}$ for ABTS/Persulphate method.

Keywords: Antioxidant activity, Brassica napus's seed, ABTS/ Persulphate, CUPRAC, DMPD Methods, Trolox
Ayca Karasakal

Namik Kemal University, Art and Science Faculty, Department of Chemistry, Tekirdağ - TURKEY

Tel: +902822502658

GSM: +90 5338117347

E-mail: aycakarasakal@yahoo.com

\section{INTRODUCTION}

Plants contain a wide variety of free radical scavenging molecules, such as flavonoids, anthocyanins, cartenoids, dietary glutathionine, vitamins and endogenous metabolites and these natural products are wealthy in antioxidant activities (1-4). Herbs have been used in many domains including medicine, nutrition, flavoring, beverages, dyeing, repellents, fragrances, cosmetics, smoking, and other industrial purposes. Since the prehistoric era, herbs have been the basis for nearly all medicinal therapy until synthetic drugs were developed in the nineteenth century (5-6). The preservative effect of many plant spices and herbs proposes the presence of antioxidative and antimicrobial constituents in their tissues (7). Recently, interest has increased greatly in finding naturally occurring antioxidants for use in foods or medicinal materials to alter synthetic antioxidants, which are being restricted due to their carcinogenicity (8). Free radicals are comprised by the physiological processes that occur naturally in the body and by external sources such as excessive exposure to sunlight 
or smoking and have been linked to several degenerative diseases (9). Although these physiological processes are in themselves not harmful, excess free radical production beyond the body's ability to cope with them can lead to immune system impairment. Oxidative stress has also been related to cardiovascular diseases, hypertension, cancer, and other ailments (10).In this study, experimental studies were performed by determining the total antioxidant capacities using three spectrophotometric methods, cupric ion reducing antioxidant capacity (CUPRAC) and 2,2'-azinobis(3-ethylbenzothiazoline-6-sulphonate) (ABTS/ Persulphate), N,N-dimethyl-p-phenylenediamine (DMPD) methods. Solvent effect is an essential parameter on the chemical behaviour of antioxidant compounds. The choice of extracting solvents with different polarities can have a significant effect on the performance of HAT (Hydrogen Atom Transfer) - and ET (Electron Transfer) - based antioxidant reactions (11-12).

This work aims to investigate the solvent effect of selected antioxidants using CUPRAC and other TAC assays. Therefore, hexane, acetone, methanol, ethanol/water mixtures of differing compositions (containing 100, 75, and 50 volume per cent of methanol), were selected as solvents. $100 \%$ hexane extraction were chosen for ABTS/Persulphate, DMPD and CUPRAC methods. Finally, Brassica napus extracts prepared in these solvent media were analyzed for antioxidant capacity by the CUPRAC, ABTS/Persulphate and DMPD methods.

\section{MATERIAL AND METHODS}

\subsection{Chemicals and Instruments}

All chemicals, solvents, reagents and standards used in the experiments were purchased from Sigma Chemical Co. All chemicals were of analytical grade. All spectrophotometric measurements were made with a pair of matched Hellma quartz cuvettes using a Shimadzu-1601 UV-VIS spectrophotometer

\subsection{Preparation of plant extracts}

Brassica napus's seeds were collected in July 2013 from different regions of Turkey. The specimens collected by the authors are deposited in the herbarium of Namık Kemal University (NAKU).

Extraction experiments were carried out with $100 \%$ hexane, $100 \%$ acetone, $100 \%$ methanol, $100 \%$ ethanol, $75 \%$ hexane-water, $75 \%$ acetone-water , $75 \%$ methanolwater, $75 \%$ ethanol-water, $50 \%$ hexane-water $50 \%$ acetonewater, $50 \%$ methanol-water, $50 \%$ ethanol-water at $25{ }^{\circ} \mathrm{C}$ overnight and mixed by magnetic stirrer for $1 \mathrm{~h}, 2 \mathrm{~h}, 4 \mathrm{~h}, 8 \mathrm{~h}$ to determine optimal extraction conditions. For $100 \%$ hexane extraction, $1 \mathrm{~g}$ sample was powdered in a mill and mixed with $40 \mathrm{ml}$ hexane and stored overnight in dark room. Then, the extract was filtered over Whatman No. 1 paper. Filtrates were removed and solutions were re-extracted with $50 \%$ acetone-water by extraction flask.Bottom phase were used for DMPD, ABTS/Persulphate and CUPRAC methods. The standard solutions at $1.0 \times 10^{-3} \mathrm{M}$ concentration of antioxidant compounds were all prepared in $100 \%$ hexane for DMPD, ABTS/Persulphate and CUPRAC methods. Solutions were re-extracted $50 \%$ acetone-water by extraction flask. All working solutions of antioxidant compounds were freshly prepared.

\subsection{Modified CUPRAC Assay (Cuprac ion reducing antioxidant activity method)}

$0.2 \mathrm{ml}$ sample was taken and added $0.5 \mathrm{~mL}$ of $2.10^{-3} \mathrm{M}$ $\mathrm{Cu}(\mathrm{II})$ chloride, $0.5 \mathrm{ml}$ ethanol, $1 \mathrm{ml}$ of $7.510^{-3} \mathrm{M}$ neocuproine solution $(\mathrm{Nc}), 1 \mathrm{ml}$ of $1 \mathrm{M} \mathrm{NH}_{4} \mathrm{Ac}$ buffer solutions ( $\mathrm{pH} \mathrm{7)}$ and $0.8 \mathrm{ml}$ ethanol to test tube so as to make the final volume: $4 \mathrm{~mL}$. $\mathrm{Nc}$ and $\mathrm{NH}_{4} \mathrm{Ac}$ solutions were prepared daily by dissolving in absolute ethanol. The tubes were stoppered, and after $1 / 2 \mathrm{~h}$, the absorbance at $450 \mathrm{~nm}\left(\mathrm{~A}_{450}\right)$ was recorded against water blank. The CUPRAC method is based on the reduction of a cupric neocuproine complex $(\mathrm{Cu}(\mathrm{II})-\mathrm{Nc})$ by antioxidants to the cuprous form $(\mathrm{Cu}(\mathrm{I})-\mathrm{Nc})$. The standard calibration curve of trolox was constructed as absorbance vs. concentration, and the molar absorptivity of the CUPRAC method for each antioxidant was found from the slope of the calibration line concerned (14).

The CUPRAC method of total antioxidant capacity (TAC) assay uses bis (2,9-dimethyl-1,10-phenanthroline: neocuproine) $\mathrm{Cu}$ (II) chelate cation as the chromogenic oxidant, which is reduced in the presence of antioxidants to the cuprous neocuproine chelate $[\mathrm{Cu}(\mathrm{I})-\mathrm{Nc}]$ showing maximum light absorption at $450 \mathrm{~nm}$. Colour development in the CUPRAC method is based on the following reaction: (15).

$n \mathrm{Cu}(\mathrm{Nc})_{2}^{+2}+n$-e reductant $\leftrightarrow n \mathrm{Cu}(\mathrm{Nc})_{2}^{+}+n$-e oxidized product $+n \mathbf{H}^{+}$

Since the calibration curve for pure trolox is a line passing through the origin, the trolox equivalent molar concentration of the plant extract sample in final solution may be found by dividing the observed absorbance to the molar absorptivity $(\varepsilon)$ for trolox (optical cuvette thickness $=1$ $\mathrm{cm}$ ). The trolox equivalent antioxidant capacity may be traced back to the original extract considering all dilutions, and proportionated to the initial mass of plant sample taken to find the capacity in the units of $\mathrm{mmol} \mathrm{TR} / \mathrm{g}$ dry matter. 
$\left(\mathrm{mmol} \mathrm{TR} \mathrm{g}{ }^{-1}\right)=\left(\right.$ Absorbance $\left./ \varepsilon_{\mathrm{TR}}\right)(4 / 0.2)(20 / 0.5)$ (100/g-plant weight) (1/dry matter \%)

where the molar absorptivity of trolox in the CUPRAC method is $\varepsilon_{\mathrm{TR}}=1.67 \times 10^{4}$

$\mathrm{Lmol}^{-1} \mathrm{~cm}^{-1}$. In CUPRAC method's analyses, Brassica napus's seeds have essantial oils. $100 \%$ hexane extraction is proved with the best solubility for CUPRAC method. 100\% hexane extraction, probably due to facilitated e-transfer in ionizing solvents capable of anion (phenolate) solution. CUPRAC assay results, expressed as the trolox equivalent antioxidant capacity.

\subsection{Determination of ABTS/persulphate assay}

For the ABTS test of TAC, the chromogenic radical reagent ABTS, at $7.0 \mathrm{mM}$ concentration, was prepared by dissolving this compound in water and adding $\mathrm{K}_{2} \mathrm{~S}_{2} \mathrm{O}_{8}$ to this solution such that the final persulphate concentration in the mixture is $2.45 \mathrm{mM}$. The resulting ABTS radical cation solution was left to mature at room temperature in the dark for $12-16 \mathrm{~h}$, and then used for ABTS assays. ABTS radical solution of blue-green colour was diluted with $96 \%$ ethanol at a ratio of $1: 30$. To $1 \mathrm{~mL}$ of the radical cation solution, $2 \mathrm{~mL}$ of ethanol were added, and the absorbance at $734 \mathrm{~nm}$ was read at the end of the sixth minute. The procedure was repeated for the Brassica napus's seed extract. To $2 \mathrm{~mL}$ of dilute sample, $1 \mathrm{~mL}$ of the radical cation solution and $4 \mathrm{~mL}$ of ethanol were added. The absorbance difference $(\Delta \mathrm{A})$ was calculated by subtracting the extract absorbance from that of the reagent blank (pure radical solution) (16).

Trolox equivalent antioxidant concentration was correlated to with the aid of a linear calibration curve.

$\left(\mathrm{mmol} \mathrm{TR} \mathrm{g}{ }^{-1}\right)=\left(\Delta \mathrm{A} / \varepsilon_{\mathrm{TR}}\right)(3.0 / 2.0)(40 / 1)(100 / \mathrm{g}$-plant weight) $(1 /$ dry matter $\%)$

where the molar absorptivity of trolox in the ABTS method is $\varepsilon_{\mathrm{TR}}=2.6 \times 10^{4} \mathrm{Lmol}^{-1} \mathrm{~cm}^{-1}$. The absorbance of the reagent blank $\left(\mathrm{A}_{0}\right)$ diminished in the presence of antioxidants, the absorbance decrease $(\triangle \mathrm{A})$ being proportional to antioxidant concentration. The decrease in absorbance $(\Delta \mathrm{A})$ caused by antioxidants, recorded at $734 \mathrm{~nm}$ against ethanol at the end of 6th min, reflected the $\mathrm{ABTS}^{\cdot+}$ radical cation scavenging capacity and was plotted against the concentration of the antioxidant. The effect of extraction solvent on radical scavenging capacity estimation was also evaluated against radical cation

\subsection{Determination of DMPD method}

The principle of the assay is that at an acidic $\mathrm{pH}$ and in the presence of a suitable oxidant solution DMPD can form a stable and colored radical cation (DMPD ${ }^{+}$). Antioxidant compounds which are able to transfer a hydrogen atom to
$\mathrm{DMPD}^{+}$quench the color and produce a discoloration of the solution which is proportional to their amount.

$1 \mathrm{ml}$ sample was taken from hexane extract To a test tube were added $0.5 \mathrm{~mL}$ of $1.10^{-2} \mathrm{M} \mathrm{FeCl}_{3}, 1 \mathrm{~mL}$ of sodium acetate buffer solution ( $\mathrm{pH} 5.7), 1 \mathrm{~mL}$ of $\mathrm{H}_{2} \mathrm{O}_{2}(3 \%)$, and $\mathrm{x}$ $\mathrm{mL}$ of sample solution, and the volume was completed to (9-x) $\mathrm{mL}$ with distilled water. The mixture was shaken after each addition and then allowed to stand on a water bath at $25{ }^{\circ} \mathrm{C}$ for $5 \mathrm{~min}$. After the addition of $4.8 \times 10^{-3} \mathrm{M}(1 \mathrm{ml})$ DMPD solution (DMPD solution at $2.4 \times 10^{-2} \mathrm{M}$ described in the original method was diluted 5 times with distilled water to get a final absorbance of $\sim 0.9-1.0$ in the absence of scavenger sample solution), the mixture was kept on the water bath for an additional $20 \mathrm{~min}$, and the absorbance in the absence or presence of sample was recorded against distilled water at $514 \mathrm{~nm}$. The decrease in absorbance in the presence of sample linearly correlated with antioxidant concentration over a reasonable range (17).

Antioxidant compounds which are able to transfer a hydrogen atom to $\mathrm{DMPD}^{\circ+}$ quench the color and produce a decoloration of the solution. This reaction is rapid and the end point, which is stable, is taken as a measure of the antioxidative efficiency. The absorbance at $514 \mathrm{~nm}$ as percentage of the absorbance of the uninhibited radical cation solution (blank) according to the equation:

DMPD(uncoloured) + oxidant $\left(\mathrm{Fe}^{+3}\right)+\mathrm{H}^{+} \rightarrow$ DMPD $^{+}$ (purple)

$\mathrm{DMPD}^{+}$(purple) $+\mathrm{AOH} \rightarrow \mathrm{DMPD}^{+}$(uncoloured) $+\mathrm{AO}$

Inhibition of $A_{514}(\%)=\left(1-A_{f} / A_{0}\right) \times 100$, where: $A_{0}$ is the absorbance of uninhibited radical cation and $A_{f}$ is the absorbance measured $20 \mathrm{~min}$ after the addition of antioxidant samples. Therefore, this assay reflects the ability of radical hydrogen-donors to scavenge the single electron from $\mathrm{DMPD}^{*+}(15,17-19)$

\section{RESULTS AND DISCUSSION}

CUPRAC, ABTS/persulphate, DMPD methods were suitable for assay of all the tested antioxidants. When regression of calibration curves carried out, good coefficients of determination were found for the three methods. The antioxidant activities of Brassica napus's seeds were investigated with different TAC methods ,extraction methods and solvents. The molar absorptivity of trolox in the above reference methods were as follows: $\varepsilon_{\mathrm{TR}}$ $=1.67 \times 10^{4} \mathrm{~L} \mathrm{~mol}^{-1} \mathrm{~cm}^{-1}$ (CUPRAC method); $\varepsilon_{\mathrm{TR}}=2.6 \times$ $10^{4} \mathrm{~L} \mathrm{~mol}^{-1} \mathrm{~cm}^{-1}$ (ABTS method). I found good coefficients of determinations in a range 0.9927-0.9992 for the CUPRAC, 0.9915-0.9982 for the ABTS/Persulphate, 0.9973-0.9996 for the DMPD method 
Solvent effects may also be considered from the standpoint of choosing the reagents encountered in common AOA assays. If the AOA assay reagent is a coordinatively saturated metal complex species (involving different oxidation states of a given metal ion in the same ligand environment such as bis(neocuproine)copper(II,I), tris(1,10phenanthroline)iron(III,II), hexacyanoferrate(III,II)) capable of outer-sphere e-transfer with the polyphenol (20), then ligand addition or removal is out of question, and a negligible reorientation of the already existing ligands around the central metal ion may expected in the formation of the transient intermediate during e-transfer, and consequently, the rate of e-transfer may only be affected to a limited extent by solvent polarity. However, innersphere e-transfer reactions of the assay reagent (e.g., $\mathrm{Fe}\left(\mathrm{H}_{2} \mathrm{O}\right)_{6}{ }^{3+}$ ) with the phenolic compound will naturally be affected by the $\mathrm{H}$ bonding behaviour of the solvent due to stabilization or inhibition of the intermediary state formed during e-transfer. When other factors are not considered or assumed to remain constant, AOA assay methods based on H-atom donation (e.g., ORAC, TRAP, and ABTS assays) from a phenolic compound are generally affected to a greater extent by the solvent behaviour (polarity, HBA, etc.) than methods based on outer-sphere e-transfer (e.g., CUPRAC, ferricyanide, and FRAP).

Amarowicz and et al. were examined crude tannins of canola and rapeseed hulls was evaluated by $\beta$-carotenelinoleate, $\alpha, \alpha$-diphenyl- $\beta$-picrylhydrazyl (DPPH) radical, and reducing power assays. Crude tannins were extracted from three samples of Cyclone canola (high-tannin) hulls and Kolner, Ligaret, and Leo Polish rapeseed (low-tannin) hulls with $70 \%(\mathrm{vol} / \mathrm{vol})$ acetone. The total phenolic content in crude tannin extracts ranged between 128 and $296 \mathrm{mg}$ of sinapic acid equivalents per $1 \mathrm{~g}$ of extract (21).

Cumby and et.al were investigated antioxidant activity and water-holding capacity of canola protein hydrolysates. Canola protein hydrolysates were prepared using commercial enzymes, namely Alcalase, an endo-peptidase and Flavourzyme with both endo- and exo-peptidase activities. The hydrolysates so prepared were effective as antioxidants in model systems, mainly by scavenging of free radicals and acting as reducing agents. This effect was concentration-dependent and also influenced by the type of enzyme employed in the process. The scavenging capacity of DPPH radicals (\%) by various concentrations of different Canola hydrolysates were ranged from $16.8 \pm 0.68$ to $73.2 \pm$ 1.30 Analysis results of Reducing power of the hydrolysate samples at different concentrations measured as absorbance (103) at $700 \mathrm{~nm}$ were ranged from $2.06 \pm 4.97$ to $91.7 \pm$ $10.0(22)$.
Table 1. Antioxidant activity results of Brassica napus's seeds collected from Turkey.

\begin{tabular}{lccc}
\hline Sample Region & $\begin{array}{c}\text { CUPRAC (TR) } \\
\mathbf{m o l} / \mathbf{g}\end{array}$ & $\begin{array}{c}\text { ABTS (TR) } \\
\mathbf{~ m o l / g}\end{array}$ & DMPD(\%) \\
\hline $\begin{array}{l}\text { Kayı village / } \\
\text { Tekirdağ }\end{array}$ & $0.33 \pm 0.06$ & $0.41 \pm 0.08$ & $12.7 \pm 0.05$ \\
$\begin{array}{l}\text { Muratlı/Tekirdağ } \\
\text { Yazır village / } \\
\text { Tekirdağ }\end{array}$ & $0.45 \pm 0.02$ & $0.39 \pm 0.09$ & $8.5 \pm 0.08$ \\
$\begin{array}{l}\text { Gündüzlü village / } \\
\text { Tekirdağ }\end{array}$ & $0.29 \pm 0.04$ & $0.36 \pm 0.01$ & $9.8 \pm 0.02$ \\
$\begin{array}{l}\text { Yenice/Çorlu/ } \\
\text { Tekirdağ }\end{array}$ & $0.37 \pm 0.03$ & $0.44 \pm 0.04$ & $11.4 \pm 0.01$ \\
$\begin{array}{l}\text { Hayrabolu/ } \\
\text { Tekirdağ }\end{array}$ & $0.39 \pm 0.02$ & $0.47 \pm 0.03$ & $8.6 \pm 0.01$ \\
$\begin{array}{l}\text { Silivri/istanbul } \\
\text { Yağcl village / } \\
\text { Tekirdağ }\end{array}$ & $0.40 \pm 0.08$ & $0.51 \pm 0.02$ & $17.1 \pm 0.03$ \\
\hline
\end{tabular}

${ }^{a}$ Values are expressed as mean \pm standard deviation $(\mathrm{n}=3$ )

${ }^{\mathrm{b}}$ TR: Trolox

Amarowicz and et al. were examined condensed tannins were extracted from beach pea, Cyclone canola hulls, evening primrose and faba bean using $70 \%$ aqueous acetone. The dried crude tannin extracts were purified on a Sephadex LH-20 column using first $95 \%$ ethanol as a mobile phase for elution of nontannin phenolics and then $50 \%$ aqueous acetone to elute tannins. The total content of polyphenolics in tannin extracts ranged between 10 and 405 mg catechin equivalents per $1 \mathrm{~g}$ extract (23).

Jun et al., investigated the antioxidant activities of various extracts from canola (Brassica napus) seed using the DPPH assay, ABTS radical assay, and reducing power. The EC50 values of the ethyl acetate fraction were 4.2, 5.3, and 4.1 times lower than those of the $80 \%$ methanol extract for DPPH radical assay, ABTS radical assay, and reducing power, respectively (24).

Canola oil is low in saturated fat and contains both omega- 6 and omega-3 fatty acids in a ratio of 2:1. If consumed, it also reduces low-density lipoprotein and overall cholesterol levels, and as a significant source of the essential omega-3 fatty acid is associated with reduced all-cause and cardiovascular mortality. Canola oil has been given a qualified health claim from the United States Food and Drug Administration due to its high levels of cholesterollowering fats (25).

Table 1 shows CUPRAC, ABTS/persulphate, DMPD method's analysis results. Antioxidant activities of Brassica napus's seeds's extracts were as follows:Yazır village >Kayı village $>$ Gündüzlü village $>$ Yenice/Çorlu $>$ Hayrabolu $>$ 
Silivri $>$ Muratlı $>$ Yacı village for CUPRAC method. Yağc1 village is highest antioxidant activity $(0.48 \pm 0.01 \mathrm{~mol} / \mathrm{g}$ trolox (TR)) and Yazır village is lowest activity $(0.29 \pm 0.04$ mol/g trolox (TR)) according to modified CUPRAC method.

The spectrophotometric assay is capable of rapid and simple determination which can be applied to antioxidant screening. Antioxidant activities of Brassica napus's seeds's extracts were as follows: Yazır village $>$ Muratl $>$ Kay 1 village $>$ Yenice/Çorlu $>$ Hayrabolu $>$ Silivri $>$ Gündüzlü village $>$ Yağc1 village for ABTS/Persulphate method. In, Yağc1 village showed the highest antioxidant activity $(0.55 \pm 0.05 \mathrm{~mol} / \mathrm{g}$ TR $)$ measured by ABTS assay, while Yazır village showed the lowest antioxidant activity $(0.36 \pm 0.01 \mathrm{~mol} / \mathrm{g} \mathrm{TR})$.

Antioxidant activities of Brassica napus's seeds's extracts were as follows: Yağc1 village $>$ Muratl $1=$ Gündüzlü village $>$ Hayrabolu $>$ Yazır village $>$ Yenice/Çorlu $>$ Kayı village $>$ Silivri for DMPD method.

Silivri is highest inhibition of \% $(17.1 \% \pm 0.03)$ and Yağc1 village is lowest inhibition of $\%(2.00 \% \pm 0.07)$ according to DMPD method

The data's are expressed as mean \pm standard deviation (SD) from three parallel measurements. The Pearson correlation analysis was performed between antioxidant activities. There were strong positive significant correlations between CUPRAC and ABTS/Persulfate methods. $(\mathrm{p}<0.05$ ). Pearson's correlation coefficient was calculated using Microsoft Excel 2010

\section{Conclusion}

This study was purposed for evaluation of the antioxidant activities of Brassica napus's seeds collected from in Turkey. Three different methods were applied in antioxidant activity analysis. The results revealed that each of the $100 \%$ hexane extracts prepared from these seeds have antioxidant activities.Antioxidant compounds show variations based on solvent type and polarity, reaction mechanism, solubility parameters as well as on an essential structural property, i.e., electron-transfer capability.

\section{Brassica napus tohumlarının antoksidan etkisinin CUPRAC, ABTS/Persülfat ve DMPD yöntemleriyle araştırılması}

\section{ÖZET}

Bu çalışmada, Brassica napus (kanola) bitkisinin tohumlarından hazırlanan ekstraktların antioksidan etkileri incelendi. Brassica napus bitkisinin tohumları Türkiye'nin sekiz farklı bölgesinden topland1. Ekstraksiyon deneylerinde optimum koşulların belirlenmesi için; $25{ }^{\circ} \mathrm{C}$ 'de $\% 100$ hekzan, $\% 100$ aseton, $\% 100$ metanol, \% 100 etanol, \% 75 hekzan-su, $\% 75$ aseton-su, $\% 75$ metanol-su, \% 75 etanol-su, \% 50 hekzan-su, \% 50 aseton-su, \% 50 metanol-su, \% 50 etanol-su çözücülerinde bir gece boyunca bekletilerek ve 1, 2, 4, 8 saat manyetik karıştırıcılarda bu çözücülerle karıştırılarak ekstraksiyonlar yapıldı. UV/VIS spektralarının sonuçlarına göre ABTS/Persülfat, DMPD ve CUPRAC yöntemleri için \% 100 hekzanla, $25^{\circ} \mathrm{C}$ 'de 1 gece boyunca bekletilen ekstraksiyon seçilerek optimum koşullar sağlandı. CUPRAC ve ABTS/Persülfat yöntemlerinin toplam antioksidan kapasitesi troloks eşdeğeri cinsinden ve DMPD yönteminde ekstraktların antioksidan kapasitesi ise DMPD radikal katyonunun inhibisyonu ile belirlendi. Brassica napus'un tohumlarının antioksidan etkileri DMPD yöntemi için inhibisyon yüzdeleri $2.00 \pm 0.07 \%$ ve $17.1 \pm 0.03 \%$ aralığında bulunmuştur.CUPRAC yöntemi analiz sonuçları $0.29 \pm 0.04$ $\mathrm{mol} / \mathrm{g}$ ve $0.48 \pm 0.01 \mathrm{~mol} / \mathrm{g}$, ABTS/Persulphate yöntemi analiz sonuçları ise $0.36 \pm 0.01 \mathrm{~mol} / \mathrm{g}$ ve $0.55 \pm 0.05 \mathrm{~mol} / \mathrm{g}$ aralığında bulunmuştur.

Anahtar Kelimeler: Antioksidan etki, Brassica napus ohumu, ABTS/Persülfat, CUPRAC, DMPD yöntemleri, trolox

\section{REFERENCES}

1. Larson RA. The antioxidants of higher plants. Phytochem 1988; 4 : 969-78.

2. Hertog MGL, Hollman PCH, Katan MB. Content of potentially anticarcinogenic flavonoids of 28 vegetables and 9 fruits commonly consumed in the Nederlands. J Agric Food Chem 1992;40: 2379-83.

3. Cao G, Sofic E, Prior RL. Antioxidant capacity of tea and common vegetables. J Agric Food Chem 1996;44: 3426-31.

4. Kivits GAA, Vam der Sman FJP, Tijburg LBM. Analysis of catechin from green and black tea in humans: a specific and sensitive colorimetric assay of total catechins in biological fluids. Int J Food Sci Nutr 1997;48: 387-92.

5. Dahanukar SA, Kulkarni RA, Rege NN. Pharmacology of medicinal plants and natural products. Ind $\mathrm{J}$ Pharmacol 2000;32: 81-118.

6. Exarchou V, Nenadis N, Tsimidou M, Gerothanassis IP, Troganis A, Boskou D. Antioxidant activities and phenolic 
composition of extracts from Greek oregano, Greek sage and summer savory. J Agric Food Chem 2002;50: 5294-9.

7. Hirasa K, Takemasa M. Spice science and technology. Marcel Dekker, New York . 1998.

8. Riaz T, Abbasi MA, Aziz-ur-Rehman, Shahzadi T, Qureshi MZ, Ajaib M. Dicliptera bupleuroides: an imperative source for protection from oxidative stress. J Chem Soc Pak 2012;34: 326-31.

9. Paravicini TM, Touyz RM. NADPH oxidase, reactive oxygen species, and hypertension. Diabetes Care 2008; 31: 170-80.

10. Çekiç SD, Çetinkaya A, Avan AN, Apak R. Correlation of total antioxidant capacity with reactive oxygen species (ROS) consumption measured by oxidative conversion. J Agric Food Chem 2013;61: 5260-70.

11. Perez-Jimenez J, Saura-Calixto F. Effect of solvent and certain food constituents on different antioxidant capacity assays. Food Res Int 2006;39: 791-800.

12. Finotti E, Majo DD. Influence of solvents on the antioxidant property of flavonoids. Nahrung/Food 2003;47: 186-7.

13. Basolo F, Pearson RG. Mechanism of Inorganic Reactions-A Study of Metal Complexes in Solution, second ed., John Wiley \& Sons, New York, 1960, pp. 303-331.

14. Baskan KS, Tutem E, Ozer N. Spectrophotometric and chromatographic assessment of contributions of carotenoids and chlorophylls to the total antioxidant capacities of plant foods. J Agric Food Chem 2013;61: 11371-81.

15. Karaman Ş, Tütem E, Başkan KS, Apak R. Comparison of total antioxidant capacity and phenolic composition of some apple juices with combined HPLC-CUPRAC assay. Food Food Chem 2010;120: 1201-9.

16. Celik ES, Ozyurek M, Guclu K. Solvent effects on the antioxidant capacity of lipophilic and hydrophilic antioxidants measured by CUPRAC, ABTS/persulfate and FRAP methods. Talanta 2010; 81: 1300-9.
17. Khatoon $\mathrm{M}$, Islam E, Islam R, Rahman AA, Alam AHM K, Khondkar P, Rashid M, Parvin S. Estimation of total phenol and in vitro antioxidant activity of Albizia procera leaves. BMC Res Notes 2013;6: 121-8.

18. Vincenzo F, Verde V, Giacomino R, Ritieni A. Method for measuring antioxidant activity and its application to monitoring the antioxidant capacity of wines. J Agric Food Chem 1999;47: 1035-40.

19. Balaydin HT, Gülçin Í, Menzek A, Göksu S, Şahin E. ynthesis and antioxidant properties of diphenylmethane derivative bromophenols including a natural product. J Enzyme Inhib Med Chem 2010; 25: 685-95.

20. Prakash D, Upadhyay G, Pushpangadan P, Gupta C. Antioxidant and free radical scavenging activities of some fruits. J Complement Integr Med 2011; 8.

21. Amarowicz R, Naczk M, Shahidi F. Antioxidant activity of crude tannins of canola and rapeseed hulls. JAOCS 2000;77: 957-61.

22. Cumby N, Zhong Y, Naczk M, Fereidoon S. Antioxidant activity and water-holding capacity of canola protein hydrolysates. Food Chem 2008; 109:144-8.

23. Amarowicz R, Naczk M, Zadernowski R, Shahidi F. Antioxidant activity of condensed tannins of beach pea, canola hulls, evening primrose, and faba bean. J Food Lipids 2000;7: 195-205.

24. Jun H, Wiesenborn DP, Kim YS. Antioxidant activity of phenolic compounds from Canola (Brassica napus) seed. Food Sci Biotechnol 2014;23: 1753-60.

25. Qualified Health Claims: Letter of Enforcement Discretion Unsaturated Fatty Acids from Canola Oil and Reduced Risk of Coronary Heart Disease (Docket No. 2006Q-0091). Avaliable in: http://www.fda.gov/Food/IngredientsPackaging Labeling/LabelingNutrition/ucm072958.htm [Accessed: 02.04.2015]. 